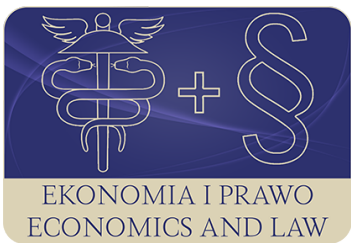

EKONOMIA I PRAWO. ECONOMICS AND LAW

Volume 20, Issue 2, June 2021

p-ISSN 1898-2255, e-ISSN 2392-1625

www.economicsandlaw.pl

EKONOMIA I PRAWO
ECONOMICS AND LAW

ORIGINAL ARTICLE

received 30.04.2021; revised 20.06.2021; accepted 30.06.2021

Citation: Mazurek-Chwiejczak, M. (2021). Polish 'sugar fee' in the light of global experience with sugar sweetened beverages taxation. Ekonomia i Prawo. Economics and Law, 20(2), 287-303. https://doi.org/10.12775/EiP.2021.017.

\title{
Polish 'sugar fee' in the light of global experience with sugar sweetened beverages taxation
}

\author{
MAEGORZATA MAZUREK-CHWIEJCZAK \\ Maria Curie-Skłodowska University in Lublin, Institute of Economics and Finance, Department \\ of Public Finance, pl. M. Curie-Skłodowskiej 5, 20-031 Lublin, Poland \\ $\square$ malgorzata.mazurek-chwiejczak@poczta.umcs.lublin.pl \\ (D) orcid.org/0000-0002-9806-1666
}

\begin{abstract}
Motivation: Obesity is one of the gravest public health challenges facing the world today. Out of different policy action undertaken by counties to counteract these threats, taxes imposed on sugar sweetened beverages (SSBs) has gaining growing popularity. They are currently imposed on 47 countries worldwide. The Polish 'sugar fee' came into force on January $1,2021$.

Aim: The aim of the article is to synthesize the global experience with sugar-sweetened beverages taxation, to assess on that basis the construction of Polish 'sugar fee' and to identify key opportunities and threats connected with its implementation.

Results: Introduction of 'sugar fee' in Poland is consistent with the latest global trends in taxation. Its formula gives an opportunity to stimulate consumers to displace SSBs by other healthier beverages and to incentivize drink manufacturers to reformulate their products and change their marketing strategies. There is growing that evidence 'sugar taxes' can be effective tools to achieve public health goals, however its effect must be strengthen by multifaceted instruments (e.g. broad information action). The fiscal potential of 'sugar fee' is limited, if we assume that its main purpose is to stimulate healthier consumption patterns.
\end{abstract}

Keywords: sugar tax; soda tax; SSBs tax; sin tax; corrective tax

JEL: H21; H23; I12; I18 


\section{Introduction}

Non-communicable diseases (NCDs) are responsible for $71 \%$ of the global deaths nowadays (WHO, 2021). One of the factors significantly contributing to their risk is too high body weight, which can be attributed to coronary heart disease, at least 12 types of cancers and type 2 diabetes. According to WHO (2017) data, in $201439 \%$ of adult population in the world were overweight and further $13 \%$ were obese (WHO, 2017). Besides harmful health consequences, obesity can also make negative socioeconomic impact. It not only generates additional health care costs, but also leads to reduction in labour supply and productivity, human capital and tax revenues (World Bank Group, 2020, p. 7). It is expected that during the period 2011-2030 diabetes will generate 1.7 USD trillion losses in gross domestic product worldwide (WHO, 2017). Another aspect is that people suffering from obesity or overweight are often self-conscious and tend to withdraw from social activity.

All those facts can be justification for public intervention aimed at improving diets and reducing the burden of diet-related non-communicable diseases. Sugar-sweetened beverages (SSBs) are well defined category of products that can be a key target. Sugar is the important contributor to excess calorie consumption. It makes up a significant portion of total energy intake with no nutritional value to diets. SSBs are the main dietary source of sugar. Regardless of causing obesity, their consumption can also contribute to tooth decay and insulin resistance (Brownell et al., 2009). SSBs consumption in advanced economies is approximately 2-3 times higher than the daily maximum recommended dose (Public Health England, 2015). According to research conducted by Harvard University (Singh et al., 2015), 184000 of global deaths can be attributed to their over-consumption. The growing concern is that level of SSBs consumption is particularly high among children and teenager adolescents (Allen \& Allen, 2020, pp. 8-15) - in this groups SSBs tend to displace other healthier beverages (e.g. water or milk).

Out of recommendations formulated by WHO (2013) to prevent NCDs, the organization emphasized the role of fiscal instruments and recommended national countries to consider implementation of sugar taxes. Currently (2021) taxes of this type are applied in all parts of the globe worldwide in the total number of 47 countries.

\section{Theoretical framework and literature review}

The economic rationale for imposing 'sugar taxes' is associated with the theory of corrective taxation. According to A.C. Pigou use of some goods imposes costs on individual consumers (negative internalities) as well as on the whole society (negative externalities) (Plott, 1966, p. 84). In the case of sugar-sweetened beverages internalities can the attributed to individual health costs, which are not taken into account when making purchases. Consumers sometimes make 
sub-optimal decisions from the their own welfare point of view. Despite raising awareness of SSBs detrimental health consequences, some groups of consumers are still under-informed and make their decisions on the basis of imperfect information (Brunello et al., 2009, pp. 551-596). All the above mentioned circumstances result in situation in which consumers do not take into account possible future costs related to excessive sugar intake. On the other hand, consumption of SSBs cause some externalities. Besides contributing to the raise of public healthcare system financing, it generates costs related to absence from work and lower productivity (Adamiec, 2020, p. 1). Both groups of future costs - internalities and externalities - are not fully reflected in SSBs prices. The essence of corrective taxes is that they have a potential to improve social welfare by reducing sub-optimally high consumption (Griffith et al., 2018, p. 2).

The issue of food taxation as a health promoting instrument has been considered in a number of scientific papers. The first area of intensified research is associated with incidence of sugar taxes. It is clear than the instrument can encourage consumers to reassess their preference for a product only if it will be pass on consumers via retail price increases (Hawkes at al., 2015). It has been proven that the burden of taxation is generally passed on consumers, although the incidence ratio varies significantly (Alvarado et al., 2017, pp. 413-416; Berardi et al., 2016, pp. 3976-3994; Colchero et al., 2015; Stacey et al., 2019, p. 112465).

There is a growing evidence that 'sugar taxes' influence consumers behavior and leads to the limitation of SSBs consumption. Research conducted by Adreyeva et al. (2011, pp. 414-416) indicates 24\% reduction in sugar-sweetened beverages consumption. Impact of similar scale (limiting volume of sales by 22\%) was estimated by Powell \& Leider (2020) for Seattle. The scale of market reaction can vary depend on the categorie of a tax product. Research conducted by Alvarado et al. (2019, pp. 1-13) proven the shift of consumption patterns to non-sugar drinks (5.2\% sales increase) and bottle water (7.5\% sales increase).

\section{Methods}

Implementation of the assumed objectives required the use of diversified research methods and tools selected for the individual stages of the research work.

An overview of SSBs taxes applied worldwide has been conducted on the basis of various data sources - World Bank Group (2020) report, materials of Global Food Research Programme UNC (2020) and the last two OECD (2020, 2021b) Tax policy reforms reports. In order to assess justification of Polish 'sugar fee' implementation, some statistical data (concerning the rates of obesity and total calories intakes) published in the OECD (2021a) Global revenue statistics database has been used.

Scientific methods used in this article include both descriptive and comparative analysis, critical analysis of legal acts, case studies as well as selected meth- 
ods of descriptive statistics (non-weighted averages, dynamic rates and measures of location - median, quartiles).

\section{Results}

\subsection{Development of SSBs taxation around the world}

'Sin taxes' have been known since 1920s and 1930s, when they were introduced in Denmark and Finland, mainly for fiscal purposes.

Contemporary duties levied on SSBs have different role and they are aimed at discouraging consumers to buy products detrimental to health. Taxes of this kind were enacted in the beginning of the 2lst century in some small Pacific islands, e.g. French Polynesia, Nauru and Fiji. Latvia, Hungary, Denmark and France have been among the first European countries, which decided to tax some categories of unhealthy food products in order to counteract obesity. Duties in this countries were enacted between 2004 and 2012 (World Bank Group, 2020, p. 62-75).

In $2013 \mathrm{WHO}$ (2013) added SSBs taxation to its menu of desirable measures for counteracting with obesity, especially among children and adolescents. Since that moment, the implementation of 'sin taxes' has gained the global momentum. Public duty of this type were imposed in 29 countries in 2017 (Adamiec, 2020, pp. 1-4) and the number climbed to 47 in 2021 (Table 1). At present 'sugar taxes' are applicable in all parts of the globe.

As of 2021 Poland joined to the group of countries imposing a special consumption tax on sugary beverages. In the nearest future Italy is going to introduce a tax on soft drink of EUR 0.10 per hectolitre for finished products. The tax, initially applicable as of October 2020, has been postponed due to COVID-19 pandemic (OECD, 2020, p. 94). What is more, it has been also announced that that Latvia is going to increase SSBs tax rate in 2022 (OECD, 202lb, p. 58).

The global expansion of SSBs taxation is still in progress and it seems to be one of the most common trends in the area of taxation nowadays, when governments are facing quick deterioration of public finance in the aftermath of COVID-19 pandemic (OECD, 2021b, p. 19) and are forced to seek additional sources of government revenue.

\subsection{Polish 'sugar fee' - justification and the construction of the duty}

The prevention of overweight and obesity should be one of the primary objectives of public health in Poland. According to OECD (202la) data excessive body weight has been observed among 53.3\% of total Polish population ${ }^{1}$. This ratio is significantly higher than both OECD average and OECD median (Table

\footnotetext{
${ }^{1}$ It should be noted that the data are based on self-reported height and weight values.
} 
2). Energy intake per person in Poland in 2018 was approximately $3537 \mathrm{kcal}$. The level is alarming when we consider that Guideline Daily Amount is 2,000 kcal for women and 2,500 for men. In 2018 the level of total calories supply was higher in only eight OECD countries (Belgium, United States, Ireland, Austria, Iceland, France, Germany and Turkey). What is more, the value of the indicator for Poland has been still increasing - in 2017 it reached the value of the OECD third quartile and in 2018 it exceeded the third quartile (Chart 1). Dynamics of total calories intake in Poland is significantly high in comparison to other OECD countries. In this circumstances it seems to be desirable and inevitable to undertake an effective form of policy action to counteract growing health, finance and social costs of excessive weight.

According to the clarification given by legislators, the aim of the new public duty is to promote healthy purchasing decisions among consumers (Kancelaria Prezesa Rady Ministrów, 2020).

The new public duty has been imposed by amendment to the Act of 11 September 11, 2015 on public health passed by Polish Parliament on February 14, 2020. Although the instrument has been named 'fee', it meets all the characteristics that can be assigned to classical taxes. It can be defined as compulsory, unrequited payment to general government (see: OECD, 1996), so the use of terms 'sugar tax', 'soda tax' or SSBs tax relative to mention fee can be fully justified and they are used in this article interchangeably.

The regulation imposing additional fee on certain types of beverages came into force on January 1, 2021. The Polish 'sugar tax' is levied on (Act amending certain acts in connection with the promotion of pro-health consumer choices, 2020):

- beverages with added sugar in the form of monosaccharides and/or disaccharides;

- foodstuffs with the content of this ingredients, including substances used for sweeting properties, as per Regulation (EC) No. 1333/2008 of the European Parliament and of the Council of December, 162008 on food additives (e.g. aspartame, xylitol, sorbitol);

- caffeine and/or taurine products ready for use.

The personal scope of taxation is limited to natural persons, legal persons and organizational units without legal personality 'placing goods on the domestic markets'.

Aforementioned entities are obliged to provide electronic declarations and pay the appropriate amount of the fees to the relevant tax offices to the 25th day of every month (KPMG, 2020).

The duty consist of two parts:

- fixed component - PLN 0.50 per 1 litre of the product - levied on all drinks with the content of sugar or/and at least one sweetener referred in the Regulation no. 1333/2008 in any amount;

- variable component - PLN 0.05 per 1 litre of the product for each gram of sugar exceesing the limit $5 \mathrm{~g}$ in $100 \mathrm{ml}$. 
Beverages containing taurine or caffeine are subjects of additional part of the fee - PLN 0.10 per 1 litre.

The total amount of the fee shall not exceed PLN 12 per 1 litre of drink.

The range of beverages exempted from the subject of new 'sugar tax' covers, inter alia, medical devices, dietary supplements and food for special medical purposes.

The vast majority of the total receipts received from that 'sugar tax' -96.5 percent - will contribute to the Polish National Health Fund with only 0.5 percent of the total revenue reaching the central budget.

\subsection{International experience with SSBs taxation}

'Sin tax' can be imposed on different categories of foodstuff - e.g. products with high content of ingredients detrimental to human's health like sugar, salt, fat (HSSF - high sugar, salt, fat) or some types of junk food (Chips tax, Chamburger tax) (Twarowska, 2016, p. 201).

Dannish fat duty, which came into force in 2011 was applied to all products with the content of this ingredient exceeding $2.3 \mathrm{~g}$ per $100 \mathrm{~g}$. Besides foodstuff with the high content of fat, it covered also meat and diary products (Jørgensen et al., 2016). The tax was repealed in 2013.

Hungarian public health product tax introduced in 2011 can be characterized as the most complex out of contemporary 'sin taxes' using worldwide. It has been imposed on wide range of products - ready-to-eat foods, salty snacks and all products with the content of unhealthy ingredients (sugar, salt and others) exceeding a certain threshold (World Bank Group, 2020, p. 66).

Taxes and other public duties which came into force in recent years are concentrated, according the WHO recommendation, on beverages with sugar content. However, in some countries besides Hungary, the material scope of 'sin' taxes is broader. In Finland, Oman, Palau, Quatar, Thailand and United Arab taxes are imposed on all carbonated soft drinks - regardless they have sugar in content or not. The tax enacted in Navajo Nation (the USA) applies to 'minimal-no-to-nutritional value food items', including prepacked and non-prepacked snacks and soft-drinks. In Nauru all sugar confectionery and high-sugar food are subject of tax.

The material scope of Polish 'sugar fee' seems to be quite broad. It covers not only beverages with content of sugar but also drinks with some artificial sweeteners - as in other 5 countries (Estonia, Fiji, France, Philippiness, Thailand) and the city of Pennsylvania (the USA). Although levying the duty on energy drinks is very common - it takes place in most countries where the instrument has been implemented - it is noteworthy than only six countries (Bahrain, Maxico, Oman, Saudi Arabia, Quatar, United Arab Emirates) imposed additional amount of fee on soft drinks — similarly to Poland.

Out of different types of taxes levied on SSBs, most jurisditions - 42 coutries and 7 regional/local units - opted for excise duties. Five countries charged 
consumers of 'sugar' drinks via raising import duties and futher two countries increased VAT rates applicable to such products (Table 3).

Out of countries which have enacted exices on sugary drinks, 29 has decided to implement specific formulas and the rest 13 countries impose ad valorem taxes . The drawback of ad valorem formulas is that they increase the price of all taxed products by the same percentage, regardless the amount of sugar added. As a result, they do not incentivize producers to reformulation of their drinks. Moreover, implementation of ad valorem taxes forces consumers to choose cheaper option, not necessary with lower content of detrimental substances.

As a result, specific excises are preferable option which should be taken into account by legislators.

We can divide specific excise taxes on sugar drinks which are currently in effect into three groups. First of them covers 5 countries (Cook Islands, France, Mauritius, South Africa and Sri Lanca) with excises based on sugar volume. This solution can be very effective, because it directly targets the ingredient (sugar) which causes negative externalities and internalities, although the construction of the tax built on this assumption is complicated, so it is recommended only for countries with sufficient administrative capacity. 26 of excise taxes on SSBs which are currently in effect are based on the product absolute volume. They are straightforward to implement and administer, however from the efficiency point of view they are poorly targeted. This formula do not incentivize to alter the recipe of a given drink. Their volume-based taxes currently are imposed on eight jurisdiction. They have progressive character and they give an impulse for producer to reduce the amount of sugar content in order to the product can be classified to the lover threshold.

\subsection{Opportunities and threats}

The construction of Polish 'sugar fee' is of hybrid character and there are some difficulties to explicitly classify it to the one of the above described groups. The Polish public duty combine some elements of tier design (the fixed amount) with the sliding scale (the variable component applied to drinks with sugar content exceeding PLN 0.05 per $100 \mathrm{ml}$ ).

In order to assess the 'sugar tax' construction it is essential to resolve if it has a potential to alter consumers choices and to incentivize producers to undertake a reaction. Polish 'sugar fee' meets this expectations. Its construction is complex and it seems to be difficult to administer, but on the other hand it is likely to be an effective instrument supporting improvement of drinking habits.

SSBs industry reaction to imposing a tax is a key determinant of sugar taxation efficiency. 'Sugar tax' has a potential to induce producers to reformulate already sold products (to limit or remove their sugar content) and to promote new or existing healthy alternatives. In the United Kingdom announcement of the HM Treasury of imposing tax on SSBs with sugar content exciding 5\% resulted several leading brands (including Ribena, Lucozade and Fanta) decided 
to reformulate their beverages (Hashem \& Rosborough, 2017, p. 358). Average reduction of sugar content is estimated at 28.8\% during the period 2015-2018 (Public Health England, 2020). It is reported that Portuguese tiered 'sugar tax' has resulted in a $41 \%$ reduction of sugar content among beverages classified in the highest tax tier (with the sugar amount exceeding $8 \mathrm{~g}$ per $100 \mathrm{ml}$ ).

Another determinant of SSBs taxation effectiveness is to choose the appropriate level of its rate. In order to achieve its non-fiscal goals, the amount of the imposed tax (and a consequent change in prices) should be perceptible from the consumer point of view. It is requested that introduction of the tax should create price differential between healthy and unhealthy products. The arguments of too low sugar taxes' rates are often raised (Popkin \& Ng, 2021, p. 6). The recommendation of WHO is that tax should increase the retail price of the product by minimum $20 \%$. Rates of ad valorem excise used worldwide ranges from 2\% in Navajo Nation and 7\% in Panama to 50\% in Bahrain, Oman, Quatar, Saudi Arabia and United Arab Emirates (Table 4). The Polish standard rate (fixed amount) of PLN 0.50 per 1 litre in comparison to levels of taxation in other countries using specific formula seems to be quite moderate (Table 5), although the wide rage of drinks are a subject of additional variable component dependent on sugar content. According to estimations provided by Center for Market Monitoring (2021), prices of SSBs in Poland rose by 32\% in comparison to recent year.

The argument raised by opponents of 'sugar taxes' regressive character can be misleading. Imposing the tax should prompt consumers to choose products with no or lower sugar content. The fact is that low-income households and young people are the most prone to changes in price levels, but on the other hand this groups have a chance to get the greater benefit of SSBs (Griffith et al., 2018, p. 3).

One of the sugar taxes main drawbacks is their week fiscal potential. Reaching the primary objective of the tax, which is to improve consumers, contradicts to its success at raising public funds. There is growing evidence that 'sin taxes' failure to generate predicted revenues. Revenue collected from the U.K. 'soda tax' in the first 6 months of its existence was reportedly less than half what had been forecasted. The similar situation took place in Philadelphia (World Bank Group, 2020, pp. 30-31). According to data published by Polish Ministry of Finance, revenues received from 'sugar fee' in the first quarter of 2021 were equal PLN 292 mln (Lubowicki, 2021). If we assume comparable amounts of the receipts gathered in following months of 2021, it will give annual income at level of PLN 1,168 bln, which is significantly lower than initially predicted PLN 3 mld. 


\section{Conclusion}

There is no doubt that obesity is one of the major threats to public health nowadays.

Implementation of SSBs has been widely use strategy to combat the high rates of overweight and obesity. There is growing evidence that imposing a tax of this kind can be an effective tool to achieve this aim. Introduction of 'sugar fee' in Poland is consistent with the latest global trends in taxation. The Polish 'tax' is based on the assumption that the amount of the duty increases with the rising sugar content. This formula gives an opportunity to stimulate consumers to displace SSBs by other healthier beverages and to incentivize drink producers to reformulate their products and change their marketing strategies - concentrate marketing action on beverages with lower sugar content.

In order to halt the epidemic of obesity, overweight and diabetes, countries need multidisciplinary strategy. It is obvious that isolated actions aimed at raising public awareness of SSBs' negative health consequences may be insufficient to achieve this aim - there is a concern that such activities will target only people already leading healthy lifestyle. It is important to supplement the effect of the duty by wide range of instruments, e.g. information action or use of consistent color-coded front of pack labelling. Imposing some restrictions on the marketing of and promotion on unhealthy food and beverages should be also considered.

\section{References}

Adamiec, D. (2020). Podatek od cukru jako narzędzie zmiany nawyków żywieniowych. Infos, 3(269), 1-4.

Adreyeva, T., Chaloupka, F.J., \& Brownell, K.D. (2011). Estimating the potential on sugar-sweetened beverages to reduce consumption and generate revenue. Preventive Medicine, 52(6), 413-416. https://doi.org/10.1016/j. ypmed.2011.03.013.

Allen, W.M.K., \& Allen, K.J. (2020). Should Australia tax sugar-sweetened beverages. Journal of Paediatrics and Child Health, 56(1), 8-15. https://doi. org/10.1111/jpc.14666.

Alvarado, M., Kostova, D., Suhrcke, M., Hambleton, I., Hassell, T., Samuels, T.A., Adams, J., \& Unwin, N. (2017). Trends in beverage prices following the instruduction of sugar-sweetened beverages in Babados. Preventive Medicine, 105, S23-S25. https://doi.org/10.1016/j.ypmed.2017.07.013.

Alvarado, M., Unwin, N., Sharp, S.J., Hambleton, I., Murphy, M.M., Samuels, T.A., Suhrcke, M., \& Adams, J. (2019). Assessing the impact of the Barbados sugar-sweetened beverage tax on beverage sales: a observational study. International Journal of Behavioural Nutrition and Physical Activity, 16(1), 13. https://doi.org/10.1186/s12966-019-0776-7. 
Berardi, N., Sevestre, P., Tépaut, M., \& Vigneron, A. (2016) The impact of a 'soda tax' on prices: evidence from French micro data. Applied Economics, 48(41), 3976-3994. https://doi.org/10.1080/00036846.2016.115094 6.

Brownell, K.D., Farley, T., Willett, W.C., Popkin, B.M., Chaloupka, F.J., Thompson, J.W., \& Ludwig, D.S. (2009). The public health and economic benefits of taxing sugar-sweetened beverages. New England Journal of Medicine, 361(16), 1599-1605. https://doi.org/10.1056/nejmhpr0905723.

Brunello, G., Michaud, P.C., \& Sanz-de-Galdeano, A (2009). The rise of obesity in Europe: an economic perspective. Economic Policy, 24(59), 551-596. https://doi.org/10.1111/j.1468-0327.2009.00226.x.

Center for Market Monitoring. (2021). Wptyw optaty cukrowej na sprzedaż napojów bezalkoholowych. Retrieved 28.05.2021 from http://www.cmr.com.pl/ wplyw-oplaty-cukrowej-na-sprzedaz-napojow-bezalkoholowych-2.

Colchero, M.A., Salgado, J.C., Unar-Munguía, M., Molina, M., Ng, S., \& Rivera-Dommarco, J.A. (2015). Changes in prices after an excise tax to sweetened sugar beverages was implemented in Mexico: evidence from urban areas. Plos One, 10(12), e0144408. https://doi.org/10.1371/journal. pone. 0144408 .

Global Food Research Programme UNC. (2020). Sugary drink taxes around the world. Retrieved 28.05.2021 from https://globalfoodresearchprogram. org/wp-content/uploads/2020/08/SugaryDrink_tax_maps_2020_August_REV.pdf.

Griffith, R., O'Connel, M., \& Smith, K. (2018). Corrective taxation and internalities from food consumption. CESifo Economic Studies, 64(1), 1-14. https:// doi.org/10.1093/cesifo/ifx018.

Hashem, K., \& Rosborough, J. (2017). Why tax sugar sweetened beverages. Journal of Pediatric Gastroenterology and Nutrition, 65(4), 358-359. https:// doi.org/10.1097/mpg.0000000000001680.

Hawkes, C., Smith, T.G., Jewell, J., Wardle, J., Hammond, R.A., Friel, S., Thow, A.M., \& Kain, J. (2015). Smart food policies for obesity prevention. Lancet, 385(9985), 2410-2421. https://doi.org/10.1016/s0140-6736(14)61745-1.

Jørgensen, T., Pisinger, C., \& Toft, U. (2016). Tax on saturated fat: does it work. European Journal of Clinical Nutrition, 70(8), 867-868. https://doi. org/10.1038/ejen.2016.110.

Kancelaria Prezesa Rady Ministrów. (2020). Projekt ustawy o zmianie niektórych ustaw $w$ związku z promocja prozdrowotnych wyborów konsumentów. Retrieved 21.05.2021 from https://www.gov.pl/web/premier/projekt-ustawy-o-zmianie-niektorych-ustaw-w-zwiazku-z-promocja-prozdrowotnych-wyborow-konsumentow.

KPMG. (2020). Poland: sugar tax, alcohol and food measures included in legislation. Retrieved 21.05.2021 from https://home.kpmg/us/en/home/ insights/2020/02/tnf-poland-sugar-tax-alcohol-food-measures-in-legislation.html. 
Lubowicki, M. (2021). $292 \mathrm{mln}$ zt z tytutu optaty cukrowej $w$ pierwszym kwartale. Retrieved 30.05.2021 from https://mypolitics.eu/en/ articles/292-mln-zl-z-tytulu-oplaty-cukrowej-w-pierwszym-kwartale.

OECD. (1996). Definition of taxes. (note by the chairman). Retrieved 30.05.2021 from https://www.oecd.org/daf/mai/pdf/eg2/eg2963e.pdf.

OECD. (2020). Tax policy reforms 2020: OECD and selected partner economies. https://doi.org/10.1787/7af51916-en.

OECD. (202la). Global revenue statistics database. Retrieved 21.05.2021 from https://stats.oecd.org.

OECD. (2021b). Tax policy reforms 2021: special edition on tax policy during the COVID-19 pandemic. https://doi.org/10.1787/427d2616-en.

Plott, Ch.R. (1966). Externalities and corrective taxes. Economica, 33(129), 8487. https://doi.org/10.2307/2552274.

Popkin, B.M., \& Ng, S.W. (2021). Sugar-sweetened beverage taxes: lessons to date and the future of taxation. Plos Medicine, 18(1), el003412. https:// doi.org/10.1371/journal.pmed.1003412.

Powell, L.M., \& Leider, J. (2020). The impact of Seattle's sweetened beverage tax on beverage price and volume sold. Economics and Human Biology, 37, 100856. https://doi.org/10.1016/j.ehb.2020.100856.

Public Health England. (2015). Sugar reduction: the evidence for action 2015. Retrieved 28.05.2021 from https://assets.publishing.service.gov.uk/government/uploads/system/uploads/attachment_data/file/470179/Sugar_reduction_The_evidence_for_action.pdf.

Singh, G.M., Micha, R., Khatibzadeh, S., Lim, S., Ezzati, M., \& Mozaffarian, D. (2015). Estimated global, regional and national disease burdens related to sugar-sweetened consumption in 2010. Circulation, 132(8). 639-666. https://doi.org/10.1161/circulationaha.114.010636.

Public Health England. (2020). Sugar reduction: report on progress between 2015 and 2019. Retrieved 28.05.2021 from https://assets.publishing.service.gov. uk/government/uploads/system/uploads/attachment_data/file/984282/ Sugar_reduction_progress_report_2015_to_2019-1.pdf.

Stacey, N., Mudara, C., Ng, S.W., van Walbeek, C., Hofman, K., \& Edoka, I. (2019). Sugar-based beverage taxes and beverage prices: evidence from south Africa's health promotion levy. Social Science and Medicine, 238, 112465. https://doi.org/10.1016/j.socscimed.2019.112465.

Twarowska, M. (2016). Opodatkowanie niezdrowej żywności: dyskusyjny instrument finansowania ochrony zdrowia i walki z otyłością. Studia Ekonomiczne, 294, 197-211.

Ustawa z dnia 14 lutego 2020 r. o zmianie niektórych ustaw w związku z promocją prozdrowotnych wyborów konsumentów [Act of February 14, 2020 amending certain acts in connection with the promotion of pro-health consumer choices] (Dz.U. 2020 poz. 1492) (Poland). 
WHO. (2013). Global action plan for prevention and control of noncommunicable diseases 2013-2020. Retrieved 15.05.2021 from file://C:/Users/pietr/ Downloads/9789241506236_eng.pdf.

WHO. (2017). Taxes on sugary drinks: why do it. Retrieved 15.05.2021 from https://apps.who.int/iris/bitstream/handle/10665/260253/WHONMH-PND-16.5Rev.1-eng.pdf; sequence=1.

WHO. (2021). Noncommunicable diseases. Retrieved 15.05.2021 from https:// www.who.int/health-topics/noncommunicable-diseases\#tab=tab_l.

World Bank Group. (2020). Taxes on sugar-sweetened beverages : summary of international evidence and experiences. Retrieved 15.05.2021 from https://openknowledge.worldbank.org/handle/10986/33969.

\section{Acknowledgements}

Author contributions: author has given an approval to the final version of the article.

Funding: this research was fully funded by the Maria Curie-Skłodowska University in Lublin.

Note: the results of this study were presented at the 8th International Conference Sustainable Finance \& Accounting: Economy, Ethics, Environment (April 19-21, 2021, Toruń, Poland). 


\section{Appendix}

\section{Table 1.}

\section{Development of sugar taxes worldwide}

\begin{tabular}{|c|c|c|}
\hline $\begin{array}{c}\text { Date } \\
\text { of implementation }\end{array}$ & Countries & Regional/local units \\
\hline 1940 & Finland (updated 2011) & - \\
\hline 1981 & Norway (updated 2017) & - \\
\hline 1984 & Samoa (updated 2008) & - \\
\hline 2002 & French Polynesia & - \\
\hline 2003 & Palau & - \\
\hline 2004 & Latvia (increased 2016) & - \\
\hline 2006 & Fiji & - \\
\hline 2007 & Nauru & - \\
\hline 2011 & Hungary, Denmark (abolished 2012) & - \\
\hline 2012 & France (updated 2018) & - \\
\hline 2013 & Tonga, Mauritius (updated 2016) & - \\
\hline 2014 & $\begin{array}{l}\text { Chile, Mexico, St Helena, Cook Island, } \\
\text { Karibati }\end{array}$ & - \\
\hline 2015 & Barbados, Dominica, Vunautu & $\begin{array}{l}\text { Berkeley (USA - California), Navajo Nation } \\
\text { (USA) }\end{array}$ \\
\hline 2016 & Belgium, Equador & ( \\
\hline 2017 & $\begin{array}{l}\text { Bahrain, Brunei, India, Maldives, Portugal, } \\
\text { Saudi Arabia (update: 2019), Sri Lanca, } \\
\text { Thailand, United Arab Emirates }\end{array}$ & $\begin{array}{l}\text { Albany (USA - California), Boulder (USA - } \\
\text { Colorado), Catalonia (Spain), Cook County } \\
\text { (USA - Illinois), Oakland (USA - California), } \\
\text { Philladelphia (USA - Pennsylvania) }\end{array}$ \\
\hline 2018 & $\begin{array}{l}\text { Estonia, Ireland, Peru, Phiippines, South } \\
\text { Africa, United Kingdom }\end{array}$ & $\begin{array}{l}\text { San Francisco (USA - California), Seattle } \\
\text { Oakland (USA - Washington) }\end{array}$ \\
\hline 2019 & $\begin{array}{l}\text { Bermuda, Colombia, Marocco, Malaysia, } \\
\text { Oman, Panama, Quatar, Seychelles }\end{array}$ & - \\
\hline 2021 & Poland & - \\
\hline
\end{tabular}

Source: Own preparation based on Global Food Research Programme UNC (2020), OECD (2021b, p. 94), World Bank Group (2020, p. 11).

Table 2.

Obesity and calories intake in Poland in comparison to OECD countries in 2018

\begin{tabular}{lcc}
\hline \multicolumn{1}{c}{ Specification } & $\begin{array}{c}\text { Overweight or obese population } \\
\text { (self-reported) }\end{array}$ as of total population & Total calories intake (kcal) \\
\hline Poland & 53.3 & 3537 \\
OECD non-weighted average & 52.3 & 3383 \\
OECD median & 52.4 & 3382 \\
OECD quartile 1 & 48.4 & 3247 \\
OECD quartile 3 & 56.2 & 3528 \\
\hline
\end{tabular}

Notes:

Obesity and overweight rates are based on the most recent data available on OECD (2021a) statistics and they are for years 2014-2020.

Source: Own preparation based on OECD (2021a). 
Table 3.

Types of public duties levied on sugar sweetened beverages worldwide

\begin{tabular}{|c|c|c|c|}
\hline Formula & $\begin{array}{c}\text { Type of public } \\
\text { duty }\end{array}$ & List of countries & $\begin{array}{c}\text { Number } \\
\text { of countries }\end{array}$ \\
\hline \multirow{4}{*}{$\begin{array}{l}\text { ad } \\
\text { valorem }\end{array}$} & import duty & Bermuda, Fiji, Nauru & 3 \\
\hline & VAT/GST & Colombia, India & 2 \\
\hline & excise & $\begin{array}{l}\text { Bahrain, Barbados, Chile, Cook Islands, Dominica, Equador, Kiribati, } \\
\text { Oman, Panama, Peru, Quatar, Saudi Arabia, Thailand, United Arab } \\
\text { Emirates, }\end{array}$ & $13+1$ \\
\hline & & Navajo Nation (USA) & \\
\hline \multirow[t]{3}{*}{ specific } & import duty & Maldives, Palau & 2 \\
\hline & excise & $\begin{array}{l}\text { Belgium, Brunei, Estonia, Fiji, Finland, France, French Polynesia, Hun- } \\
\text { gary, Ireland, Latvia, Malaysia, Marocoo, Mauritius, Mexico, Noway, } \\
\text { Philippines, Poland, Portugal, Samoa, Seychelles, South Africa, Sri } \\
\text { Lanka, St Helena, Thailand, Tonga, United Kingdom, Vanuatu, }\end{array}$ & $29+8$ \\
\hline & & $\begin{array}{l}\text { Catalonia (Spain), Albany (USA), Berkeley (USA), Boulder (USA), Philadel- } \\
\text { phia (USA), Oakland (USA), Seattle (USA), San Francisco (USA) }\end{array}$ & \\
\hline
\end{tabular}

Source: own preparation based on Global Food Research Programme UNC (2020), OECD (2021b, p. 94), World Bank Group (2020, p. 11).

Table 4.

An overview of ad valorem taxes imposed on sugar sweetened

\begin{tabular}{|c|c|c|c|}
\hline Country & $\begin{array}{c}\text { Type of public } \\
\text { duty }\end{array}$ & $\begin{array}{c}\text { Basic } \\
\text { rate }(\%)\end{array}$ & Additional notes \\
\hline Bermuda & import duty & 75 & - \\
\hline Fiji & import duty & 32 & $\begin{array}{l}32 \% \text { - the rate applied on SSBs, } 10 \% \text { — the rate on powders } \\
\text { and preparations used to make beverages }\end{array}$ \\
\hline Nauru & import duty & 30 & - \\
\hline Colombia & VAT & 19 & - \\
\hline India & GST & 40 & $28 \%$ GST $+12 \%$ cess - tax upon a tax \\
\hline Bahrain & excise & 50 & $50 \%$ on soft drinks, $100 \%$ on energy drinks \\
\hline Barbados & excise & 10 & - \\
\hline Chile & excise & 10 & $\begin{array}{l}10 \% \text { on sugary drinks with less than } 6.25 \text { g of sugar per } 100 \mathrm{ml} ; 18 \% \\
\text { on sugary drinks with }>6.25 \text { g of sugar per } 100 \mathrm{ml}\end{array}$ \\
\hline Dominica & excise & 10 & - \\
\hline Equador & excise & 10 & $\begin{array}{l}10 \% \text { on sugary drinks with less than } 25 \text { g of sugar per } 1 \text { liter and all } \\
\text { energy drinks; USD } 0.018 \text { per gram of sugar on drinks with }>25 \mathrm{~g} \\
\text { of sugar per } 1 \text { litre }\end{array}$ \\
\hline Kiribati & excise & 40 & - \\
\hline Oman & excise & 50 & $\begin{array}{l}50 \% \text { on all carbonated drinks except sparkling water; } 100 \% \text { on en- } \\
\text { ergy drinks }\end{array}$ \\
\hline Panama & excise & 7 & $\begin{array}{l}7 \% \text { on carbonated SSBs; } 5 \% \text { on another nonalcoholic SSBs; } 10 \% \\
\text { on syrups and concentrates used to produce sugary drinks }\end{array}$ \\
\hline Peru & excise & 17 & $\begin{array}{l}10 \% \text { on drinks with less than } 6 \text { g of sugar per } 100 \mathrm{ml} ; 25 \% \text { on drinks } \\
\text { with > } 6 \text { g of sugar per } 100 \mathrm{ml}\end{array}$ \\
\hline Quatar & excise & 50 & $\begin{array}{l}50 \% \text { on carbonated SSBs and concentrates intended to made into } \\
\text { carbonated drinks; } 100 \% \text { on energy drinks }\end{array}$ \\
\hline Saudi Arabia & excise & 50 & $50 \%$ on all SSBs; $100 \%$ on energy drinks \\
\hline
\end{tabular}




\begin{tabular}{llcl}
\hline \multicolumn{1}{c}{ Country } & $\begin{array}{c}\text { Type of public } \\
\text { duty }\end{array}$ & $\begin{array}{c}\text { Basic } \\
\text { rate (\%) }\end{array}$ & \multicolumn{1}{c}{ Additional notes } \\
\hline Thailand & excise & 14 & $\begin{array}{l}\text { l4\% on artificial mineral water, soda water, carbonated soft drinks } \\
\text { with and without sugar or other sweeteners and flavours; } 10 \% \\
\text { on fruit and vegetable juices }\end{array}$ \\
$\begin{array}{l}\text { United Arab } \\
\text { Emirates }\end{array}$ & excise & 50 & $\begin{array}{l}\text { 50\% on carbonated soft drinks, except sparkling water and on all } \\
\text { ready-to drink drinks containig sugar or other sweeteners, as well as } \\
\text { concentrates, gels, powders used to make beverages and a range off } \\
\text { food products; 100\% on energy drinks }\end{array}$ \\
$\begin{array}{l}\text { Navajo Nation } \\
\text { (USA) }\end{array}$ & excise & 2 & -
\end{tabular}

Source: own preparation based on Global Food Research Programme UNC (2020), OECD (2021b, p. 94), World Bank Group (2020, p. 11).

\section{Table 5.}

\section{An overview of specific taxes imposed on sugar sweetened}

\begin{tabular}{|c|c|c|c|}
\hline Country & Basic rate & Rate in USD & Additional notes \\
\hline \multicolumn{4}{|r|}{ sugar based } \\
\hline Cook Islands & $\begin{array}{l}\text { NZD } 0.001 \\
\text { per } \lg \end{array}$ & USD 0.064 & - \\
\hline France & - & - & $\begin{array}{l}\text { sliding scale tax starting at } 1 \mathrm{~g} \text { sugar per } 100 \mathrm{ml} \text { and rising } \\
\text { to EUR } 0.20 \text { (USD 0.24) on drinks with }>11 \mathrm{~g} \text { sugar/100 ml }\end{array}$ \\
\hline Mauritius & MUR 0.03 per $1 \mathrm{~g}$ & USD 0.0008 & - \\
\hline South Africa & ZAR 0.021 per $1 \mathrm{~g}$ & USD 0.0013 & tax is applied when the content of sugar is $>4 \mathrm{~g} / 100 \mathrm{ml}$ \\
\hline $\begin{array}{l}\text { Sri Lanca } \\
\text { volume based }\end{array}$ & USD 0.30 per 1 gr & USD 0.30 & - \\
\hline Belgium & EUR 0.068 per $\mathrm{L}$ & USD 0.081 & - \\
\hline Fiji & FJD 0.35 per L & USD 0.17 & - \\
\hline Finland & EUR 0.22 per L & USD 0.26 & - \\
\hline $\begin{array}{l}\text { French } \\
\text { Polynesia }\end{array}$ & CFPF 40 per L & USD 0.40 & rate on imported sweetened beverages: CFPF 60 per L \\
\hline Hungary & HUF 7 per L & USD 0.02 & $\begin{array}{l}\text { rate on concentrated syrups used to sweetened drinks: HUF } \\
200 \text { per L }\end{array}$ \\
\hline Italy & - & - & - \\
\hline Latvia & EUR 0.074 per L & USD 0.09 & - \\
\hline Maldives & MVR 4.60 per L & USD 0.30 & rate on energy drinks: MVR 33.64 per L \\
\hline Marocco & MAD 0.7 per $\mathrm{L}$ & USD 0.08 & $\begin{array}{l}\text { the standard rate is applied on soft and non-carbonated } \\
\text { drinks with >= } 5 \text { g sugar/100 l; MAD 0.6 PER L on energy } \\
\text { drinks }\end{array}$ \\
\hline Mexico & MXN 1 per $L$ & USD 0.05 & special tax of $25 \%$ has been applied to energy drinks \\
\hline Norway & NOK 3.34 per L & USD 0.36 & $\begin{array}{l}\text { rate on concentrated syrups used to sweetened drinks: NOK } \\
20.32 \text { per L }\end{array}$ \\
\hline Palau & $\begin{array}{l}\text { USD } 0.28175 \\
\text { per L }\end{array}$ & USD 0.2818 & - \\
\hline Philippiness & PHP 6 per L & USD 0.12 & rate on drinks containing HFCS: PHP 12 per L \\
\hline Poland & - & - & - \\
\hline Samoa & WST 0.4 per L & USD 0.17 & - \\
\hline Seychelles & SCR 4 per L & USD 0.22 & $\begin{array}{l}\text { tax is applied on drinks with the content of sugar }>=5 \text { per } \\
1 \mathrm{~L}\end{array}$ \\
\hline St Helena & GBP 0.75 per $L$ & USD 1 & - \\
\hline
\end{tabular}




\begin{tabular}{|c|c|c|c|}
\hline Country & Basic rate & Rate in USD & Additional notes \\
\hline Tonga & TOP 1 per L & USD 0.44 & - \\
\hline Vanuatu & VUV 50 per L & USD 0.44 & - \\
\hline Albany (USA) & USD 1 per ounce & USD 1 & - \\
\hline Berkeley (USA) & USD 1 per ounce & USD 1 & - \\
\hline Boulder (USA) & USD 2 per ounce & USD 2 & $\begin{array}{l}\text { tax is applied on drinks with the content of sugar }>=5 \mathrm{~g} \text { per } \\
12 \text { fluid ounces }\end{array}$ \\
\hline Oakland (USA) & USD 1 per ounce & USD 1 & $\begin{array}{l}\text { tax is applied on drinks to which one or more sweeteners } \\
\text { have been added and that contain >= } 25 \mathrm{kcal} \text { per } 12 \text { fluid } \\
\text { ounces }\end{array}$ \\
\hline $\begin{array}{l}\text { Philadelphia } \\
\text { (USA) }\end{array}$ & $\begin{array}{l}\text { USD } 1.5 \text { per } \\
\text { ounce }\end{array}$ & USD 1.5 & - \\
\hline $\begin{array}{l}\text { San Francisco } \\
\text { (USA) }\end{array}$ & USD 1 per ounce & USD 1 & $\begin{array}{l}\text { tax is applied on drinks containing added sugar and }>=25 \\
\text { kcal per } 12 \text { fluid ounces }\end{array}$ \\
\hline Seattle (USA) & $\begin{array}{l}\text { USD } 1.75 \text { per } \\
\text { ounce }\end{array}$ & USD 1.75 & $\begin{array}{l}\text { additional rate of USD } 1 \text { per ounce is applied to manufac- } \\
\text { turers with a worldwide gross income of }>\text { USD } 2 \text { mln but < } \\
\text { USD } 5 \mathrm{mln}\end{array}$ \\
\hline \multicolumn{4}{|c|}{ tier-volume based } \\
\hline Brunei & BDN 0.40 per $\mathrm{L}$ & USD 0.29 & the rate is applied on SSBs with $>6 \mathrm{~g} / 100 \mathrm{ml}$ total sugar \\
\hline Estonia & EUR 0.1 per L & USD 0.12 & $\begin{array}{l}\text { the rate is applied on artificially sweetened drinks and prod- } \\
\text { ucts with } 5-8 \mathrm{~g} \text { sugar } / 100 \mathrm{ml} \text {; EUR } 0.30 \text { per L on products } \\
\text { with sugar content }>8 \mathrm{~g} / 100 \mathrm{ml}\end{array}$ \\
\hline Ireland & EUR 0.20 per L & USD 0.24 & $\begin{array}{l}\text { standard rate is applied on drinks with }>5 \text { g total sugar } / 100 \\
\text { ml; EUR } 0.30 \text { per L on drinks with }>8 \text { g total sugar } / 100 \mathrm{ml}\end{array}$ \\
\hline Malaysia & MYR 0.40 per L & USD 0.10 & $\begin{array}{l}\text { the rate is applied on drinks with }>5 \mathrm{~g} \text { total sugar } / 100 \mathrm{ml} \text {, } \\
\text { milk-based drinks with }>7 \mathrm{~g} \text { per } \mathrm{L} \text { and fruit and vegetables } \\
\text { drinks with }>12 \mathrm{~g} \text { added sugar } / 100 \mathrm{ml}\end{array}$ \\
\hline Portugal & EUR 0.08 per L & USD 0.10 & 0.16 EUR per L on drinks with $>8$ g total sugar $/ 100 \mathrm{ml}$ \\
\hline $\begin{array}{l}\text { Spain } \\
\text { (Catalonia) }\end{array}$ & EUR 0.08 per $\mathrm{L}$ & USD 0.10 & $\begin{array}{l}\text { standard rate is applied on drinks with } 5-8 \text { sugar } / 100 \mathrm{ml} \text {; } \\
\text { EUR } 0.12 \text { per L on drinks with }>8 \mathrm{~g} \text { total sugar } / 100 \mathrm{ml}\end{array}$ \\
\hline Thailand & THB 0.10 per L & USD 0.0031 & $\begin{array}{l}\text { the rate is applicable on drinks with } 6-8 \mathrm{~g} \text { sugar } / 100 \mathrm{ml} \text {; } \\
\text { THB } 0.30 \text { on drinks with } 8-10 \mathrm{~g} \text { sugar } / 100 \mathrm{ml} \text {; THB } 0.50 \\
\text { on drinks with } 10-14 \text { sugar } / 100 \mathrm{ml} \text {; THB } 1 \text { on drinks with > } \\
15 \text { sugar } / 100 \mathrm{ml}\end{array}$ \\
\hline $\begin{array}{l}\text { United } \\
\text { Kingdom }\end{array}$ & GBP 0.18 per $L$ & USD 0.24 & $\begin{array}{l}\text { standard rate is applied on drinks with } 5-8 \text { g sugar } / 100 \mathrm{ml} \text {; } \\
\text { GBP } 0.24 \text { per L on drinks with }>8 \text { g total sugar } / 100 \mathrm{ml}\end{array}$ \\
\hline
\end{tabular}

Source: own preparation based on Global Food Research Programme UNC (2020), OECD (2021b, p. 94), World Bank Group (2020, p. 11). 


\section{Chart 1.}

Total calories intake in Poland in comparison to OECD countries in the period 20072018 (kcal)

3600

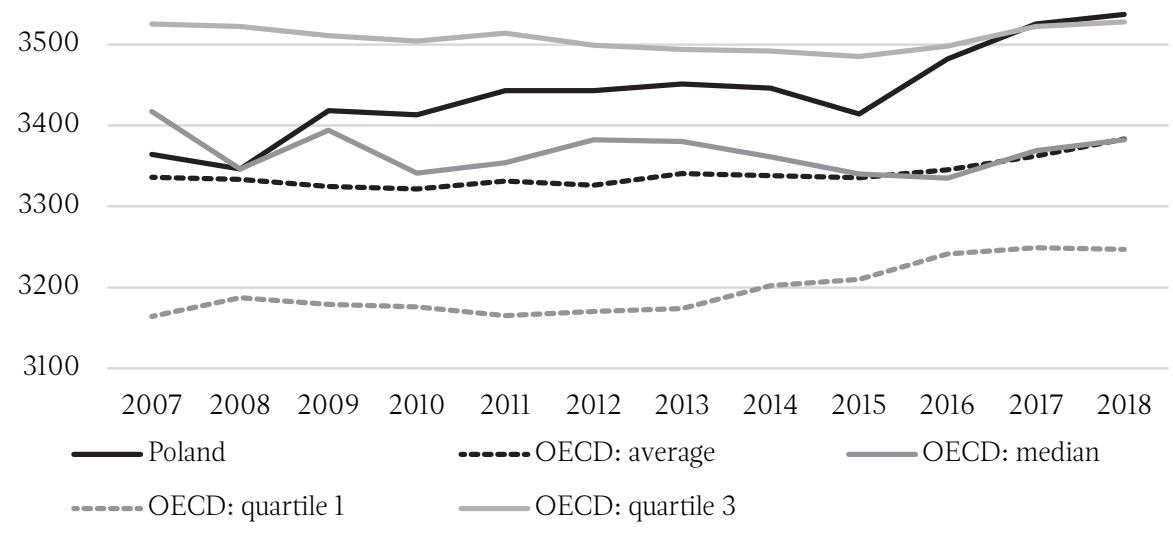

Source: Own preparation based on OECD (2021a). 
